\title{
The New Tax Regime for Expatriates in Spain
}

\author{
Begoña Pérez-Bernabeu, Tax Law Professor, University of Alicante
}

\section{Introduction}

Section 1 (1)(iv) of Act 62/2003 of 30 December concerning social, administrative and fiscal measures (Official Spanish Gazette (BOE) of 31 December) amends the Natural Persons' Income Tax Act 40/1998 of 9 December and other tax rules (BOE of 10 December) by introducing a new para. 5 in 5.9 , which became applicable on 1 January 2004.

This precept is now found in s. 9(5) of the Consolidated Version of the Natural Persons' Income Tax Act, passed by Legislative Royal Decree 3/2004 of 5 March (BOE of 10 March).

Subsequently, this precept was developed by Royal Decree $687 / 2005$ of 10 June, which amends the Natural Persons' Income Tax Regulation, passed by Royal Decree $1775 / 2004$ of $30 \mathrm{July}$, so as to regulate the special regime for non-residents' income tax and raise the percentage of expenses difficult to justify for farmers and stock breeders using the simplified direct assessment method (BOE of 11 June), with the incorporation of a new Title VII 'Special regime for non-residents' income tax'.

Likewise, questions relating to the filing of $\operatorname{tax}$ returns were developed by Ministerial Order 1731/ 2005 of 10 June, which establishes the model of natural persons' income tax return to be used by those who pay income tax under the special regime for nonresidents, as well as the form to be used by the taxpayer to notify that he is opting to pay tax under this regime, and amends some provisions concerning other tax return forms used when the regime is applied (BOE of 11 June).

This legislation envisages the possibility that natural persons who acquire their tax residence in Spain as a consequence of their transfer to this country may opt to pay tax applying the rules of the Non-Residents' Income Tax Act (rather than those of the Natural Persons' Income Tax Act, which is the general case envisaged in the legislation) during the fiscal year in which the change of residence takes place and the five subsequent fiscal years, provided that certain requisites are complied with.

This article focuses on this regime, which a priori appears to be the most favourable, and the objective is to discover any possible disadvantages for the taxpayer that may arise if this option is not exercised properly. Likewise, our aim is to demonstrate the cases and conditions in which it is not advisable for the taxpayer to exercise the option of applying the non-residents' rules envisaged by Spanish legislation.

\section{New special regime for non-residents' income tax}

\section{A. Contents of the special regime}

Spanish legislation allows income taxpayers who fulfil certain conditions to choose between paying tax under the natural persons' income tax rules or under the nonresidents' income tax rules (which in the latter case implies application of the special regime) without renouncing their status as natural persons' income taxpayers.

If a taxpayer opts for application of this special regime, the personal income tax debt is determined in accordance with the rules set out in the Non-Residents' Income Tax Act (except the provisions in sections 5, 6, $8,9,10$ and 11). However, it will be applicable only to the Spanish-source income that is not obtained through a permanent establishment.

Application of the following rules should be mentioned.

- Taxpayers who opt for this special regime will pay tax separately on each total or partial accrual of income liable to tax, and it is not possible to compensate one item of income with another.

- The assessment base for each item of income is calculated pursuant to section 24 of the NonResidents' Income Tax Act.

- The total tax liability is calculated applying the tax rates envisaged in s. 25(1) of the Non-Residents' Income Tax Act to the assessment base.

- The differential tax liability is obtained applying the deductions envisaged in s. 26 of the NonResidents' Income Tax Act to the total tax liability. Under s. 26(b), in addition to the withholdings made by the paying agent, the payments made by the individual himself on account of the nonresidents' income tax are also deductible.

\section{Individuals to whom this special regime is applicable}

As set out in s. 9(5) of the Consolidated Version of the Income Tax Act and envisaged in s. 111 of the Natural Persons' Income Tax Regulation, amended by Royal Decree $687 / 2005$ of 10 June, 'this regime is applicable to natural persons who acquire their tax residence in Spain as a result of their transfer to Spanish territory'.

The notion of 'tax residence in Spain' deserves special attention. Section 48 of the General Tax Act provides the criteria for establishing that the tax residence is in Spain. This precept provides, firstly, that for natural persons (the case we are interested in) their 
tax domicile is the place where they have their habitual residence.

Section 9 of the Consolidated Version of the Natural Persons' Income Tax Act lays down the criteria for establishing the 'habitual residence' of natural persons. This precept provides that a taxpayer is deemed to have his 'habitual residence' in Spanish territory in any of the following circumstances.

(a) He remains for more than 183 days $^{1}$ a year in Spanish territory. In order to determine the time spent in Spain, sporadic absences are taken into account, ${ }^{2}$ unless the taxpayer certifies that he is a tax resident of another country. In the case of countries or territories classified as tax havens, the tax authorities may demand proof that he spends 183 days a year therein. When calculating the time spent in Spain, temporary stays as a consequence of obligations incurred under unpaid cultural or humanitarian collaboration agreements with Spanish authorities are not taken into account.

(b) The main nucleus or base of his economic interests or activities is directly or indirectly located in Spain. The concept of nucleus of interests has been interpreted by the Spanish authorities as meaning the place where most of the taxpayer's investments are concentrated, where his business headquarters are located or where his property is administered. It can also be mean the place where he obtains most of his income. ${ }^{3}$

(c) It is assumed, unless there is evidence to the contrary, that the taxpayer has his habitual residence in Spanish territory when, in accordance with the above criteria, his spouse (from whom he is not legally separated) and children who are minors and dependent on him habitually reside in Spain.

Despite the provisions relating to habitual residence and as envisaged in s. 48 of the General Tax Act, in the case of natural persons who mainly carry on economic activities, the tax authorities may consider their tax domicile to be the place where administration and management of the activities carried on is effectively centred rather than their place of habitual residence. If such a place cannot be established, the place where the greatest value of immovable property in which the economic activities are carried on is considered the tax residence.

These provisions are understood subject to any special rules that agreements to avoid double taxation may contain.

\section{Requisites for application of this regime}

Natural persons who acquire their tax residence in Spain as a consequence of their transfer to Spanish territory may opt to pay non-residents' income tax provided they comply with the following conditions.

1. They had not been a resident of Spain in the ten years prior to their transfer to Spanish territory.

2. Their transfer to Spain is a consequence of an employment contract. This condition is considered fulfilled when an ordinary, special or statutory employment relationship is initiated with an employer in Spain, or when the transfer is ordered by the employer, who issues an employee transfer letter, and the taxpayer does not obtain income through a permanent establishment in Spain.

3. The work is effectively performed in Spain. This condition is considered fulfilled even when part of the work is performed abroad, provided that the salary received for such work - regardless of whether it is considered income obtained in Spanish territory under s. 13(1)(c) of the Consolidated Version of the Non-Residents' Income Tax Act, enacted by Legislative Royal Decree 5/ 2004 of 5 March - does not exceed 15 per cent of the total salary received for work performed in each calendar year. When, pursuant to the provisions of the employment contract, the taxpayer renders his services abroad in another company belonging to the same group, in the terms laid down in s. 42 of the Spanish Commercial Code, the limit is 30 per cent. When the specific amount of earnings corresponding to work performed abroad cannot be accredited, it is calculated based on the number of days the worker effectively spends abroad.

4. The work is performed for a company or entity resident in Spain or for the permanent establishment in Spain of a non-resident entity. This condition is considered fulfilled when the work benefits a company or entity resident in Spain or the permanent establishment in Spain of a nonresident entity. If the transfer takes place within a group of companies, in the terms laid down in s. 42 of the Commercial Code and exclusively in such a case, the worker must be hired by the company resident in Spain or the transfer to Spain be ordered by the employer.

5. The earned income arising from this employment relationship is not exempt from non-residents' income tax.

\section{Notes}

The Act does not require that they be consecutive, theretore, they may be alternate.

2 The Act does not define the concept of sporadic absences, and they should be understood to include occasional or periodic periods abroad such as holidays, business trips, etc. The authorities have interpreted that absences are temporary as long as habitual residence in another country is not accredited. Absences are no longer considered temporary for the purpose of determining the time spent in Spain if there is a tax certificate attesting that the habitual residence has been acquired in another state (Director-Generalship of Taxation, 27 June 1997 and 23 February 2000).

3 Director-Generalship of Taxation, 27 April 1992. 


\section{Exercising the option}

Exercising the option to pay tax under this special regime is entirely up to the taxpayer providing he fulfils all the necessary requirements. However, in order to exercise this option the individual must file a notification (form 149) at the regional office of the National Tax Administration Agency corresponding to his tax domicile or at the Large Companies Administration Unit of the National Tax Inspection Office when large companies are involved.

The notification must include at least the following data: personal details of the employee, the employer and, where appropriate, the company or entity resident in Spain or permanent establishment for which the services are rendered, the date of entry in Spain and the date of commencement of the activity, which appears on the document attesting to registration with the Spanish Social Security or, where appropriate, on the documents that allow the Social Security legislation of the source country to be applied.

The notification must be submitted within six months of the date of commencement of the activity, which appears on the document attesting to registration with the Spanish Social Security or, where appropriate, the documents that allow the Social Security legislation of the source country to be applied.

However, under s. 114 of the Natural Persons' Income Tax Regulation introduced by Royal Decree $687 / 2005$ of 10 June, taxpayers who have applied the special procedure envisaged in s. 87 of this Regulation to determine the withholdings and payments on account made on their earned income may not exercise this option. This special procedure allows employees who are not natural persons' income taxpayers, but who will acquire this status as a result of their transfer to Spain, to notify the tax authorities of this circumstance so that the appropriate withholdings may be made.

In our opinion, the wording of this precept may give rise to a problem of interpretation, since it is not clear whether exercise of this option is incompatible with the simultaneous application of the special procedure to determine the withholdings or payments on account, or with the simple fact that this procedure had already been applied at some time in the past.

Study of the special tax regime for non-residents' income tax and the special procedure to determine the withholdings and payments on account made on earned income when there is a change of residence, together with the fact that s. 114(3) of the Natural Persons' Income Tax Regulation does not specify the period of time prior to exercise of the option within which applying the special procedure to determine payments on account would make it impossible to take advantage of this special regime, leads us to conclude that what prevents opting for this special regime is having opted for the special procedure to determine withholdings and payments on account made on the same income and in the same fiscal years as those to which the special regime would be applied.

This notification must be accompanied by the following documents.
- When an ordinary, special or statutory employment relationship is initiated with an employer in Spain, a document issued by the employer certifying that he acknowledges the statutory or employment relationship, and stating the date the activity commenced, which appears on the document attesting to registration with the Social Security, the name and address of the place of work, the term of the employment contract and that the work will effectively be performed in Spain.

- In the case of a transfer ordered by the employer so that services may be rendered to a company or entity resident in Spain or to a permanent establishment in Spain, a document issued by the latter certifying that they acknowledge the services will be rendered to them, together with a copy of the employee transfer letter issued by the employer, and stating the date the activity commenced, which appears on the document attesting to registration with the Spanish Social Security or, where appropriate, the documents enabling the Social Security legislation of the country of origin to be applied, the name and address of the place of work, the duration of the employee transfer order, and that the work will effectively be carried out in Spain.

When the tax administration receives this notification that the option is to be exercised, it will, if appropriate, issue to the taxpayer within ten working days of the notification being filed, a document certifying that the taxpayer has opted for this special regime. This document accredits before persons or entities obliged to make withholdings or payments on account that the person concerned is a taxpayer under this special regime.

Under the provisions of the new s. 118 of the Natural Persons' Income Tax Regulation, income taxpayers who opt for application of this special regime may request a certificate attesting to tax residence in Spain. This certificate, however, has no effect as far as application of the double taxation treaties are concerned.

The certificate of tax residence in Spain is a document issued by the Spanish tax administration to natural persons' income taxpayers who must accredit their tax residence in Spain before the tax authorities of other countries or territories, or before paying agents or other economic operators abroad. It is regulated in the second additional provision of Ministerial Order 3626/2003 of 23 December.

Requests for a certificate of tax residence in Spain are submitted to the regional office of the National Tax Administration Agency corresponding to the tax domicile of the interested party or, where appropriate, to the Central Large Companies Administration Unit or the competent regional Large Companies Administration Unit.

The taxpayer may file the request electronically or in hard copy. The administration will carry out the appropriate verification and in a maximum of ten working days after filing of the request will issue a certificate in the same format as the request was made or, where appropriate, will issue a notification that the request has been refused. 
If reciprocity with other states exists, the Minister or Finance may indicate the cases in which certificates will be issued attesting to the tax residence in Spain, for the purposes of the provisions of an agreement to avoid international double taxation subscribed by Spain, of taxpayers who have opted for application of this special regime.

\section{Duration of the special regime, waiver of and exclusion from the regime}

The provisions of Royal Decree 687/2005 of 10 June, amending the Natural Persons' Income Tax Regulation, affect the fiscal years from 1 January 2004 on and apply during the fiscal year in which the taxpayer acquires his tax residence in Spain $^{4}$ plus the five subsequent fiscal years. However, duration of this special regime is understood without prejudice to waiver thereof or exclusion therefrom. In the case of waiver or exclusion, the interested party must file a notification of the same, which, in the case of exclusion, includes the date of non-fulfilment of the requirements necessary to opt for this regime (form 149).

Taxpayers who opted for this special regime may waive its application only during the months of November and December prior to the calendar year in which the waiver will take effect.

Waiver is effected in accordance with the following procedure.

1. The interested party submits a notification of his situation to the withholder, and the withholder must give him back a stamped copy of the notification.

2. The taxpayer files with the tax administration another notification (form 149), together with the stamped copy of the notification given to the withholder. This second notification must be filed at the regional office of the National Tax Administration Agency corresponding to the taxpayer's tax domicile, or to the Large Companies Administration Unit of the corresponding Special Office of the National Tax Administration Agency or to the Central Large Companies Administration Unit of the National Tax Inspection Office, as appropriate.

If the taxpayer waives this special regime he will not be able to opt for its application again. Given that the legislation makes no specific provision in this respect, we understand that the taxpayer will not be able to opt for its application until he once again complies with the necessary requirements.

Exclusion from the regime occurs when taxpayers who opted for application of this regime, after exercising the option, fail to fulfil all the conditions necessary for its application. Exclusion takes effect in the fiscal year in which failure to fulfil the conditions occurs.

Taxpayers excluded from the regime should notify the tax administration within a month of failure to fulfil the conditions determining its application. This is done by filing a notification (form 149) with the tax administration. This notification should be filed at the regional office of the National Tax Administration Agency corresponding to the taxpayer's tax domicile, or at the Large Companies Administration Unit of the corresponding Special Office of the National Tax Administration Agency or the Central Large Companies Administration Unit of the National Tax Inspection Office, as appropriate.

\section{Withholdings and payments on account}

Individuals who take advantage of this special regime are obliged to support withholdings and make payments on account. The withholdings and payments on account are made in accordance with the legislation on non-residents' income tax. However, in addition to individuals obliged to make withholdings and payments on account pursuant to this legislation, resident entities or permanent establishments in which the taxpayers render their services in exchange for the Spanish-source income are also obliged to make withholdings when the taxpayers are paid by an entity, whether resident or not, that is not the entity for which the services are rendered but a related entity, or when payment is made by the owner abroad of the permanent establishment in Spain.

The person obliged to make withholdings and payments on account is also obliged to fulfil certain formal obligations consisting in filing a tax return for the amount withheld and corresponding payments made on account in accordance with the natural persons' income tax legislation. ${ }^{5}$ The form to be used is the one envisaged for non-residents' income tax when the income is not obtained through a permanent establishment (form 216).

\section{Obligation to file a return}

Taxpayers under this special regime are obliged to file and sign a natural persons' income tax return. The tax debt must be calculate and the corresponding amount deposited when the return is filed. The return must be filed within the period established each year for filing natural persons' income tax returns. If the tax return results in a tax debt, the return may be filed and the amount of the self-assessed debt deposited in any of the

\section{Notes}

4 For this purpose, the fiscal year in which tax residence is acquired in Spain is considered to be the first calendar year during which, after the transfer has taken place, the taxpayer remains for more than 183 days in Spain.

5 Section 106 of Royal Decree 1775/2004 of 30 July enacting the Natural Persons' Income Tax Regulation (BOE no. 187 of 4 August 2004). 
entities in Spain that collaborate in the collection procedure (banks, savings banks or credit cooperatives), even when payment is deposited outside the established period of time.

In the case of tax returns that result in a tax credit, the return may be filed at any regional office of the National Tax Administration Agency or at any office in Spain of the collaborating entity in which the taxpayer wishes to receive the refund, even in this case if the return were filed late. These returns may also be sent by registered mail to the regional office of the National Tax Administration Agency corresponding to the taxpayer's tax domicile or, where appropriate, to the Central Large Companies Administration Unit of the National Tax Inspection Office, or the Large Companies Administration Unit of the corresponding Special Office of the National Tax Administration Agency. In all cases, it is necessary to provide the number of the client's account to which the transfer is to be made. ${ }^{6}$

In the case of returns that result in no tax debt or those in which the taxpayer renounces the refund in favour of the Treasury, such returns are filed either directly at any regional office of the National Tax Administration Agency or sent by registered mail to the regional office of the National Tax Administration Agency corresponding to the taxpayer's tax domicile or, where appropriate, to the Central Large Companies Administration Unit or the corresponding Large Companies Administration Unit.

\section{Advisability of exercising the option depending on the amount of income: comparison of non- residents' and natural persons' income tax}

We compare two simple cases with the aim of determining which regimen is the most advisable for each situation.

Let us assume that an individual goes to Spain in order to work in that country. He/she is not married, he/she acquires a habitual dwelling in Spain ${ }^{7}$ and he/ she fulfils all the requirements to exercise the option.

First, assume that this individual has a taxable income of $€ 19,500$. In this case, if the individual did not exercise the option, it would result a tax payment of $€ 992$, whereas if he/she exercised the option, it resulted tax payment of $€ 3,650$. As can be seen, if the individual exercised the option, he/she would pay $€ 2,658$ more.

Assume the same individual, but now he/she has a taxable income of $€ 96,500$. In this new situation, in the same conditions than before, if the individual did not exercise the option, it would result a tax payment of
$€ 29,480.62$. Contrary to if he/she exercised the option, it would result a tax payment of $€ 22,500$, which means that if the individual exercised the option, he/she would pay $€ 6,980.62$ less.

As can be clearly seen, this special regimen especially advisable for high incomes. The main reason is that, in the special regimen the high IRPF tax rates do not apply to the high income (which would have been the ordinary situation). Instead of it, high incomes enjoy a lower fixed rate of 25 per cent. As result, the tax payment is considerably lower, although, because of having exercised the option, deduction for habitual dwelling, deduction for labour rents and a personal exemption are not possible.

On the other hand, non exercising the option is more suitable for lower incomes, because lower IRPF tax rates apply to them and because lower incomes can enjoy the deduction for habitual dwelling, deduction for labour rents and a personal exemption of $€ 3,400$ deductible from the annual income.

Of course, this explanation is based on general situations, and the suitability of the particular regimen for each concrete case depends on an exactly study of the situation. Besides that, for didactical reasons we have not considered the payments on account and withholdings which the individual may have suffered. Of course, these withholdings and payments on account should be taken into account once the liability has been calculated. These payments on account and withholdings muss reduce the final tax payment and, in most of the cases, it may occur that the individual has right to a tax refund.

\section{Advisability of opting for the special regime when immovable property, in particular, the habitual dwelling, is to be transferred}

As we have already mentioned, a person who exercises this option pays tax under the non-residents' income tax rules without losing his status as a natural persons' income taxpayer. This must be borne in mind if the individual wishes to sell property that he acquired in Spain. The most common case is that of a person who, when he is transferred to Spain, buys a home in this country where he resides and then subsequently sells it when the employment relationship that was the reason for his transfer is terminated.

Income derived from sale of the habitual dwelling in Spain is considered 'capital gains' under the Spanish tax rules.

The treatment given to capital gains derived from the sale of the habitual dwelling in Spain under the natural persons' income tax legislation is different

\section{Notes}

6 When the taxpayer does not have an acconnt in a collaborating entity in Spain, he may make this known in a written statement accompanying his return addressed to the director of the corresponding regional office of the National Tax Administration Agency, who after verifying this fact will order the appropriate refund to be made in the form of a cheque from the Bank of Spain, either crossed or payable to the bearer. In the case of taxpayers who come under the jurisdiction of the Large Companies Administration Units, the written statement is addressed to the director of the corresponding Special Regional Office of the National Tax Administration Agency or to the head of the National Tax Inspection Office. Likewise, refunds may be made by crossed or bearer cheques from the Bank of Spain when they cannot be made by bank transfer. 
from that given under the non-residents' income tax rules. We shall now describe the most relevant characteristics of both types of legislation.

\section{(a) Natural persons' income tax rules}

The amount of capital gains in the case of the sale of the habitual dwelling is calculated as the difference between the purchase price and the selling price. On the one hand, the purchase price is the sum of the actual price paid and the amount spent on improvements plus associated taxes and expenses, except amortization. ${ }^{8}$ On the other, the selling price of the habitual dwelling is calculated by subtracting the associated taxes and expenses from the actual price paid by the buyer.

It is important to note that in the case of capital gains derived from the transfer of immovable property not associated with economic activities, certain updating coefficients are applied ${ }^{9}$ so as to correct for the inflation implicit in this type of gains.

Under the natural persons' income tax rules, capital gains are treated differently depending on whether they are considered to be generated in more than one year (if more than one year has passed between the purchase and the sale of the dwelling) or less than one year (if less than one year has passed between the purchase and the sale of the dwelling).

Capital gains generated in more than one year are integrated and compensate for each other. They may give a positive or a negative result. If the result is positive, this amount is included in the special part of the tax base. If the result is negative, it is compensated for with the positive balance of profits and losses of the same type in the following four years. Once the general tax base and the special tax base have been calculated, the reductions envisaged in the tax legislation are made. If the general tax base becomes zero before all the reductions have been applied, any left over reductions are made to the special tax base which includes the positive result of the capital gains generated in more than one year. After making the reductions we are left with the 'assessment base'. The general and special assessment bases can never be negative.

The tax rate envisaged in the legislation is then applied to the general assessment base, ${ }^{10}$ whereas a flat rate of 15 per cent is applied to the special assessment base (in which we included the capital gains derived from the sale of the habitual dwelling).

Once the net tax liability has been calculated, deductions, including the deduction for investment in the habitual dwelling, are made. As a general rule, this deduction is 10 per cent of the amount spent on acquiring or rehabilitating the habitual dwelling, up to a maximum of $€ 9,015.18$. However, this percentage changes if the individual has obtained outside financing, provided that two requirements are met. In these cases, during the first two years after acquiring or rehabilitating the dwelling, 16.75 per cent is applied to the first $€ 4,507.59$ and 10.05 per cent to the rest, up to a maximum of $€ 9,015.18$. After the first two years, the percentages are 13.4 per cent and 10.05 per cent respectively.

The two requisites that must be complied with in order to apply these higher coefficients are, in simple terms, that at least 50 per cent of the purchase price or rehabilitation costs of the dwelling be financed and that during the first three years no more than 40 per cent of the total amount borrowed be amortized.

However, it should be mentioned that the natural persons' income tax legislation envisages a total exemption of capital gains derived from the sale of the habitual residence when the transferrer is over 65 years of age.

Likewise, another exemption is envisaged in cases of re-investment. This exemption applies to capital gains derived from transfer of the habitual dwelling. The natural persons' income tax legislation provides that for a dwelling to be considered a habitual residence for these purposes it must have been the taxpayer's residence for a continuous period of at least three years. Nevertheless, the dwelling shall be understood to be habitual when, despite this period not having passed, the taxpayer dies or other circumstances arise that make it necessary for him to change residence, for example, he gets married, separates from his spouse, is transferred by his employer, obtains his first job, changes to a better job, etc.

To be able to take advantage of this exemption, the person must purchase another habitual dwelling and re-invest in this new dwelling the sum obtained from the sale of his previous dwelling. This re-investment must be made in a lump sum or in various instalments within a period of two years. A point that could have special importance for those who are transferred as a consequence of an employment contract is that the location of the new dwelling is irrelevant. It may be in the same Spanish town where the taxpayer resided previously or even in a country outside the European Community.

For the natural persons' income tax regime to be applied as explained above, the worker who is transferred must be a taxpayer, he must sell his habitual dwelling in the fiscal year in which he is liable to pay natural persons' income tax (that is, in which he

\section{Notes}

We also assume that the individual enjoys the maximum quantity of deduction for habitual dwelling.

Amortization is not applicable to inmovable property used as the habitual dwelling but only to immovable property associated with economic activitics.

9 These coefficients are found in s. 57 of the General State Budgets Act for 2004 (Act 61/2003 of 30 December) (BOE 31 December 2003) and s, 57 of the General State Budgets Act for 2005 (BOE 28 December 2004).

10 Two scales are envisaged - a general one and an autonomic or complementary one. 
is considered a resident of Spain), and not have opted for this special regime.

Capital gains generated in less than a year are integrated and compensate for each other. They may give a positive or a negative result. If the result is positive, this amount is included in the general part of the income obtained in the fiscal year. On the other hand, if the result is negative, it is compensated for with the positive balance of earnings and imputation of income in the same fiscal year, up to a limit of 10 per cent of the positive balance. Any outstanding amount will be compensated for in the following four years in the same way, that is, first with the positive balance of gains and losses of the same type (generated in a period of no more than one year) and secondly, with the positive balance of earnings and imputation of income, again up to a maximum of 10 per cent. In no case is it possible to compensate after a period of four years with the capital losses accumulated in subsequent years.

In all other aspects, there are no variations under this regime.

\section{(b) Non-residents' income tax legislation}

Under the tax regime applicable to capital gains obtained by non-residents without a permanent establishment in Spain, the tax base is calculated in a similar way to that in the case of natural persons' income tax. However, there are various differences.

One of the differences is that this taxation is limited to capital gains, and capital losses are not taken into account when calculating the tax. Accrual of capital gains is understood to take place when the change in capital occurs. Moreover, no rule is envisaged allowing the tax to be deferred or paid in instalments in the case of forward transactions or those with deferred payment, unlike what happens in the case of natural persons' income taxpayers.

One point to bear in mind is that the purchaser of immovable property in Spain, the transferrer of which is a non-residents' income taxpayer acting without a permanent establishment, is obliged to withhold and deposit $^{11} 5$ per cent of the agreed price as a withholding or payment on account of the non-residents' income tax to be paid by the non-resident seller.

The tax base is calculated, for each change in networth that takes place, in accordance with the rules envisaged in the natural persons' income tax legislation. However, we can say that, in general, the tax base is the difference between the purchase price of the property concerned and its sale price, while it is not possible to apply the following:

- compensation of gains or increases in net-worth with losses or decreases in net-worth;
- the tax deferral regime, envisaged for cases of transfer of shares in collective investment institutions;

- exemption for re-investment in the purchase of another property to be used as the habitual dwelling;

- exemption of increases in capital derived from the sale of the habitual dwelling in the case of taxpayers over 65 years old.

However, it is possible to apply the up-dating coefficients to the purchase price.

Capital gains obtained by non-residents without a permanent establishment are taxed at the flat rate of 35 per cent.

Once the tax liability has been calculated, the only possible deductions are:

- any withholdings made on account of the 5 per cent of the agreed consideration;

- a deduction for donations.

\section{Taking advantage of the special regime and the benefits envisaged in the agreements to avoid double taxation subscribed by Spain}

The possibility that taxpayers who benefit from this special regime may also take advantage of the benefits envisaged by a double taxation treaty (DDT) should be considered. We must remember that individuals who benefit from this tax regime are residents of Spain that are considered natural persons' income taxpayers and, under this special regime for which they may voluntarily opt, pay tax pursuant to the provisions of the non-residents' income tax legislation, without losing their status as natural persons' income taxpayers.

It would be only logical to think that since they are residents of Spain, having acquired this status due to the fact that they were transferred to Spain to perform their work, there are no obstacles to them benefiting from the provisions of the double taxation treaties signed between Spain and other states. However, Art. 4(1) of the OECD Model Tax Treaty defines residents as follows:

'For the purposes of this Convention, the term "resident of a Contracting State" means any person who, under the laws of that State, is liable to tax therein by reason of his domicile, residence, place of management or any other criterion of a similar nature, and also includes that State and any political sub-divisions or local authority thereof. This term, however, does not include any person who is liable

\section{Notes}

11 However, there are two cxceptions to the obligation of making this withlolding:

(a) when the owner of the property transferred it a natural person and, at 3 I December 1996, the property had formed part of his personal wealth for more than ten years and no improvements had been made;

(b) when the transferrer accredits he is liable to natural persons' income tax or corporate tax by means of a certificate issued by the tax administration;

(c) in the case of contribution of immovable property when incorporating resident companies or increasing their capital. 
to tax in that State in respect only of income from sources of that State or capital situated therein.'

Most of the DTTs subscribed by Spain follow the wording of the Model Convention on this point. Therefore, in cases in which the convention contains the provision envisaged in the second sentence of this Article, the person cannot take advantage of the DTT in question since for purposes of this treaty he is not a resident of Spain. Vice versa, in the cases in which the DTT subscribed by Spain does not contain this clause, the person may take advantage of the provisions, since for the purposes of the treaty in question he is considered a resident of Spain.

It should be remembered that, as we have already mentioned, the certificate of tax residence that the individual who avails himself of this tax regime requests from the Spanish tax administration has no effect as far as application of the DTTs is concerned. However, despite this last excluding provision in Art. 4 in a DTT subscribed by Spain, the Minister or Finance may indicate the cases in which a certificate attesting to the tax residence in Spain of taxpayers who avail themselves of this special tax regime may be issued for purposes of the DTT in question if reciprocity with the other state exists.

Table 1 shows a list ${ }^{12}$ of the various DTTs subscribed by Spain which do contain this exclusion clause and Table 2 lists the DTTs that do not contain such a clause.

\section{Table 1 Conventions with an exclusion clause}

\begin{tabular}{ll}
\hline Argentina & Italy \\
Belgium & Latvia \\
Bolivia & Lithuania \\
Chile & Luxembourg \\
South Korea & Mexico \\
Cuba & Norway \\
Slovakia & Poland \\
Slovenia & Portugal \\
United States & United Kingdom \\
Philippines & Czech Republic \\
France & Romania \\
Greece & Russia \\
Hungary & Sweden \\
Iceland & Thailand \\
India & Tunisia \\
Iceland & Turkey \\
Israel & Venezuela \\
& \\
\hline
\end{tabular}

We should not forget that a person who is effectively a resident of Spain, since he fulfils all the necessary requisites, is not - pursuant to the exclusion clause in Art. 4 of the DTT - regarded as such for the purposes of a DTT subscribed by Spain, and he may not fulfil the requirements necessary to be considered a resident of the other Contracting State either.

\section{Table 2 Conventions with no exclusion clause}

\begin{tabular}{ll}
\hline Germany & Ex-Soviet Republics (except \\
Australia & those that have a specific \\
Austria & DTT) \\
Brazil & Finland \\
Bulgaria & Indonesia \\
Canada & Japan \\
China & Morocco \\
Denmark & Netherlands \\
Ecuador & Switzerland \\
\end{tabular}

In this case, the result is that the person is liable to tax as a non-resident in both states, and only pays tax under the 'real obligation' system. This means he does not pay tax on his worldwide income in either state, so the progressive effect of the taxes in both states is avoided with the resulting tax savings. If we refer to the comments on the first paragraph of Art. 4 of the OECD Model Tax Convention, we can see that no provision is made to mitigate this situation.

At this point we should ask ourselves whether the Spanish tax administration has some type of mechanism that enables the worldwide income of individuals who have opted for this special regime to be subject to taxation. In this respect, we could mention an administrative practice used by the Spanish tax authorities whereby an individual does not lose his status as a resident of Spain until he submits a certificate of residence in another state in which he has acquired his new tax residence. If this practice were applied to these cases, the result would be that Spain would consider the person who opted for this special regime a resident for the purposes of taxation in the framework of a DTT, and his worldwide income would then be liable to tax.

However, we consider that this type of administrative practice is impossible for two obvious reasons. First, a state's internal administrative practice can not contravene the provisions of a DTT to which it has subscribed. Secondly, taxing the worldwide income of an individual who has opted for application of this special regime, the essence of which is to subject to Spanish tax only the property or rights obtained in Spain, for the sole purpose of preventing the individual from benefiting from the fact that his worldwide income is not taxed in any state, is completely illogical.

Therefore, we believe that these situations in which the individual pays tax only under the 'real obligation' system in the two states and which contradict the spirit of the DTTs should be corrected by statute, introducing a provision that eliminates the effects of the exclusion clause in Art. 4(1) of the DTT in cases in which its application leads to the individual not being considered a resident of either of the two Contracting States with the result that taxation of his worldwide income is avoided.

\section{Notes}

12 Source: Martín-Abril and D. Clavo, 'El nuevo régimen de tributación por el impuesto sobre la renta de no residentes o régimen de 'Impatriados', Carta Tributaría Monografias 2005, no. 16, p. 20. 
It would be advisable to introduce this provision in the DTT itself. However, due to the fact that amending all the DTTs subscribed by Spain that contain this clause would be a lengthy and expensive process, it would be most advisable to introduce a provision for this purpose in the new regime developed by Royal Decree $687 / 2005$ of 10 June regulating the special tax regime for non-residents' income tax, which is the subject of this article.

\section{Consequences for wealth tax}

An individual becomes a wealth taxpayer if he owns property or rights in Spain. However, there are two ways of paying tax: one is under the 'personal obligation' system - paying tax in Spain on all the property he owns regardless of whether it is in Spain or abroad - and the other under the 'real obligation' system, paying tax only on the property and rights located in Spain.

In general, residents of Spain must pay wealth tax under the personal obligation system, whereas nonresidents who have property or rights in Spain would do so under the real obligation system.

Section $9(5)$ of the Consolidated Version of the Natural Persons' Income Tax Act envisages that natural persons' income taxpayers who exercise the option to pay tax under this special regime will pay wealth tax under the real obligation and not the personal obligation system, as would have been the case if they had not exercised the option since they are considered residents of Spain.

In the case of workers who are transferred to Spain by their employers, it is highly likely that they own property in their country of origin which they did not want to get rid of since their transfer to Spain might well be temporary. In these cases - and in others in which the person is the owner of property or rights located outside Spain, especially if the property or rights have a high monetary value - those who avail themselves of this special regime receive a benefit since they are not obliged to pay tax under the real obligation system as the property and rights they possess in states other than Spain are not taxed, which they would be under the real obligation system.

However, it is not advisable to generalize concerning the advantages of the real obligation system, but rather the particular circumstances of each case should be considered when deciding whether or not it is recommendable. Correct analysis of a specific case should take into consideration two factors. First, the possibility of benefiting from the provisions laid down in the DTTs when tax is paid under the personal obligation system, since in this case, the individual has not opted for this special regime and so may benefit from such provisions.

Secondly, the tax regime applicable to those who pay tax under the real obligation system is characterized by the fact that the individual who has opted for this special regime:

- cannot avail himself of the exemptions envisaged in s. 14 of the Consolidated Text of the NonResidents' Income Tax Act, whereas a non-resident of Spain who pays wealth tax under the real obligation system can avail himself of these exemptions;

- cannot benefit from the exemption of a minimum amount, whereas wealth taxpayers under the personal obligation system can do so;

- must in any case file a wealth tax return ${ }^{13}$ unlike the situation of taxpayers under the personal obligation system who are only bound to file a return if their net wealth is more than the exempt minimum;

- cannot benefit from the regime of the sum of the total wealth tax liability and the general part of the natural persons' income tax base, since this is only applicable to those who pay tax under the personal obligation system.

\section{Notes}

13 The form to be filed is form D-714 and the period in which to file the return is the same as that for natural persons' income tax returns. A special period was established for filing the return corresponding to 2004, which ran from 12 June 2005 to 12 September 2005. 